\title{
蛙皮膚-Melanophoren ノ運動二關スル研究
}

\section{第 3 編}

\section{腦下垂體後葉えきすニヨル Melanophoren-撗張作用二 及ボス Cocain 並二其二, 三類似藥ノ影響二就テ}

\author{
松田弘 \\ (長崎醫科大學樂理學敉室) \\ (昭和九年十一月十三日受付[特])
}

\section{緒言}

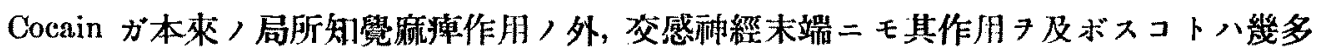
實驗七ラレタル所ナリ.而シテ Cocainノ Melauophoren，變動二及ボス影響二就テハ

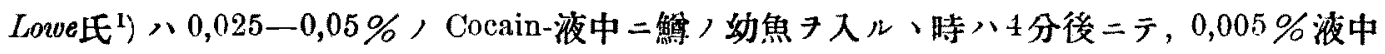

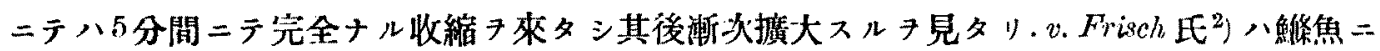
於テCocain，局所塗㑈八Melanophoren，收縮 7 起 スコト

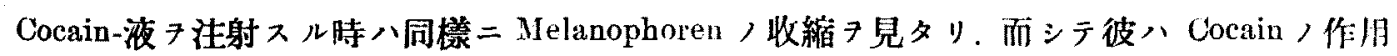

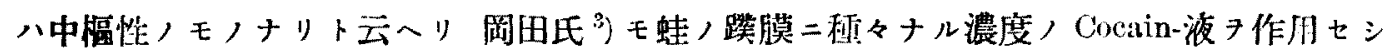
メタル $=0,1 \%$ 以下，濃度二テ八何等影響ナキモ， $0,15-0,5 \%$ ニテルッ20分後二シ

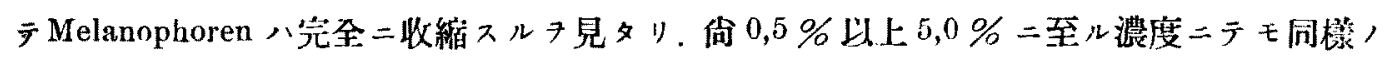
結果 7見タリ．而シテLowe氏ノ見タル如タ Melanophoren，收縮後摭大ノ來ルコト八其例 フ見ザリキト云へリ。

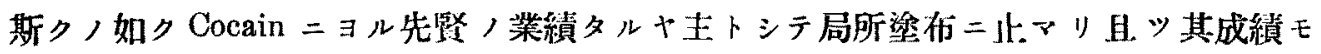
見ルベキモノ蓼々タリ。

茲二於テ余、Cocain 並二其代用架タルTutocain, Pantocain 度ビ Novocain 7 月七テ蛙:

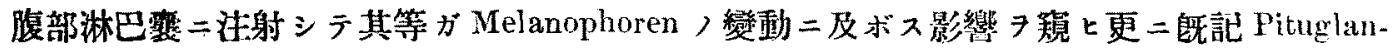
dol ニヨル Melanophoren-擴張作用二對シテ如何ナル影響テ及ボスカタ觀察シ，次，如キ賽 驗成績 得タルキ以テ次二其大略尹報告セントス。 


\section{蹇 驗 方 法}

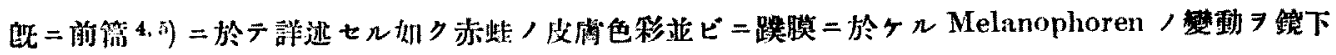

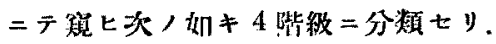

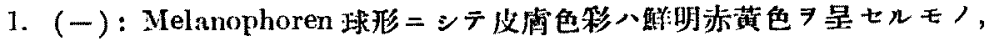

2. $(+)$ : 短突起星状 ニシテ稍々着色セルモノ，

3. (H)：長笑起星狀 $=シ テ$ 中等度二着色セれモノ，

4. (井): 網狀ニシテ嘴黑赤色ナルモノ.

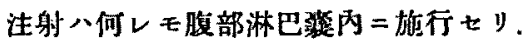

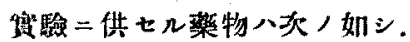

Cocain HCl (局方), Thtocain (Bayer), Pantocain (Bayer) 及ビ Novocain (局方).

\section{實 驗 成 綪}

\section{Cocain $\mathrm{HCl}$}

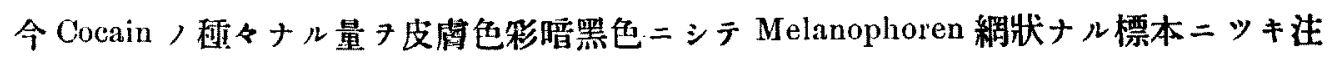

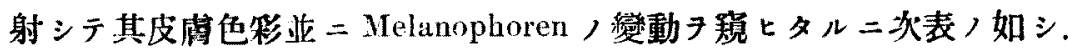

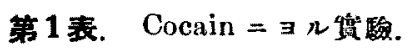

\begin{tabular}{|c|c|c|c|c|c|c|c|c|c|c|c|c|c|c|c|}
\hline \multirow{3}{*}{$\begin{array}{l}\text { 蛙 } \\
\text { 番 } \\
\text { 躆 }\end{array}$} & \multirow{3}{*}{$\begin{array}{l}\text { 繁 } \\
\text { (g) } \\
\text { 重 } \\
\end{array}$} & \multirow{3}{*}{$\begin{array}{c}\text { 注射量 } \\
\left(\begin{array}{c}10 \mathrm{~g} \\
\mathrm{mg}\end{array}\right)\end{array}$} & \multicolumn{13}{|c|}{ Melanophoren，形狀並=皮消色移 } \\
\hline & & & \multirow{2}{*}{$\begin{array}{l}\text { 洼 } \\
\text { 射 } \\
\text { 前 }\end{array}$} & \multicolumn{5}{|r|}{ 法 } & \multicolumn{2}{|c|}{ 射 } & \multicolumn{2}{|l|}{ 後 } & \multirow[b]{2}{*}{$2 "$} & \multirow[b]{2}{*}{$3 "$} & \multirow[b]{2}{*}{$4 "$} \\
\hline & & & & $1 / 12$ 時 & $1 / 6 "$ & $1 / 4$ & $1 / 3$ & $5 / 12 ”$ & $1 / 2$ & $2 / 3$ & $5 / 6$ & ]" & & & \\
\hline 1 & 15 & \multirow{3}{*}{0,01} & \# & Ht & th & Ht & H & H & $H$ & H & H & Ht & 曲 & H & $H$ \\
\hline 2 & 11 & & H & $H$ & $H$ & $H$ & $H$ & \# & \# & H & H & Ht & $\#$ & H & $H$ \\
\hline 3 & 10 & & H & $H$ & H & $H$ & H & HH & H & 卅 & H & H & $H$ & H & Ht \\
\hline 4 & 9 & \multirow{3}{*}{0,1} & Ht & H & H & + & + & + & + & ++ & + & + & + & $H$ & $H$ \\
\hline 5 & 10 & & 州 & $H$ & $H$ & $H$ & $H$ & $\#$ & $H$ & $H$ & $H$ & Ht & H & \# & H \\
\hline 6 & 11 & & HH & $H$ & $H$ & $H$ & $H$ & $H$ & $H$ & $H$ & $H$ & $H$ & $H$ & Ht & H \\
\hline 7 & 16 & \multirow{5}{*}{1,0} & $H$ & $H$ & + & + & + & - & - & - & - & - & - & + & + \\
\hline 8 & 13 & & H. & $H$ & + & + & + & $t$ & - & - & - & - & - & - & + \\
\hline 9 & 12 & & $H$ & $H$ & $H$ & + & + & + & - & - & - & - & + & + & H \\
\hline 10 & 11 & & HI & $H$ & H & + & + & + & - & - & - & - & - & - & + \\
\hline 11 & 14 & & H & $H$ & $H$ & + & + & - & - & - & - & - & + & + & $H$ \\
\hline 12 & 15 & \multirow{3}{*}{2,0} & H & $H$ & $H$ & + & + & + & - & - & - & - & - & - & + \\
\hline 13 & 16 & & $H$ & $H$ & + & + & - & - & - & - & - & - & - & + & + \\
\hline 14 & 13 & & $H$ & $\#$ & $H$ & + & + & - & - & - & - & - & - & - & + \\
\hline
\end{tabular}

第 1 表二示ス如ク $0,01 \mathrm{mg}$ 對 $10 \mathrm{~g} ニ ア リ テ ハ$ 注射前網狀ナリシ Melanophoren 八依然

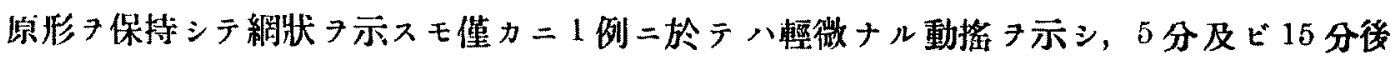

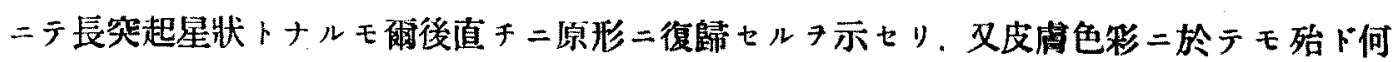




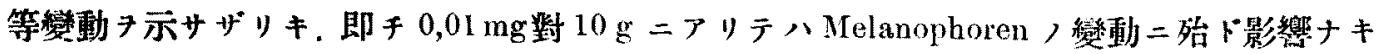
力或ハ極メテ僅微ナル收緶的傾向 キ示七リ。

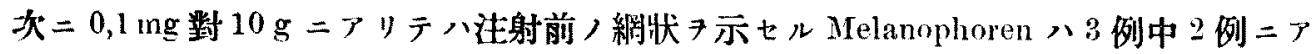
リテハ5 分後ニシテハ何レモ原形子保持シテ網狀タ示スモ, 10 分後ニテ八共二稍々收繀シ テ長突起星狀トナリ爾後數時閒二百リ現狀キ保チ然ル後原形二向ツテ復歸スルタ認メタリ. 他） 1 例ニアリテハ5 分後ニシテ稍く收縮シテ長突起星狀トナリ, 15 分後ニシテ更二短突

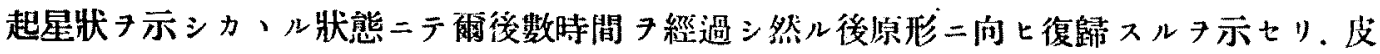

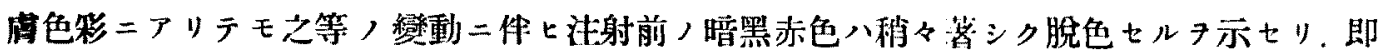

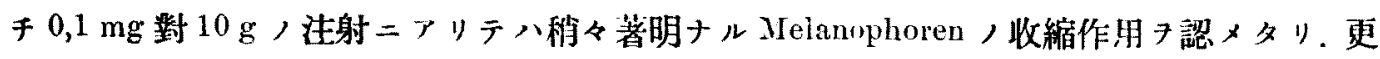
$=1,0 \mathrm{ng}$ 對 $10 \mathrm{~g}$ ニアリテハ注射前網狀ナリシ Melanophoren 八注射 5 分後ニシテハ何レ、 長突起星狀トナリ，10-15 分後二シテ八更二短突起星㹜トナリ，20-30 分後ニシテ何レモ

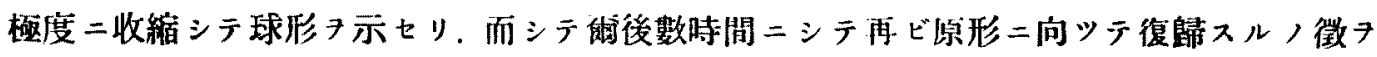

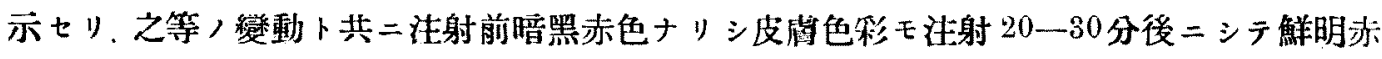
㣴色二脫色セルォ見タリ. 即千 $1,0 \mathrm{mg}$ 對 $10 \mathrm{~g}$ ノ注射ニアリテハ㱠ド完全ナル Melanophoren

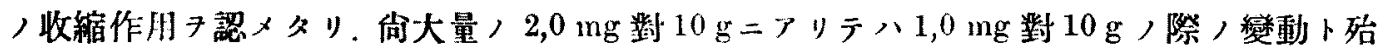
ド同一ナル經過キ示シ注射前網狀ナリシ Melanophoren 八注射 20 -30 分後ニシテ完全二收 縮シテ球狀トナリ攵暗黑赤色トナリ皮處色彩モ完全二脫色シテ鮮明赤黃色トナレリ. 蓋シ

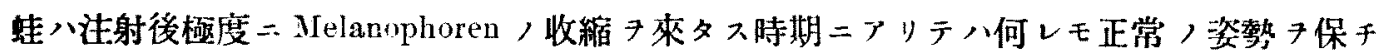

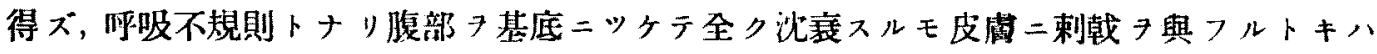

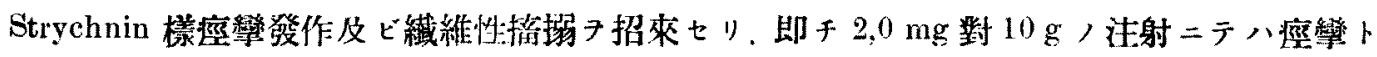
トモ二完全ナル Melanophoren，收縮キ來スキ認メクリ。

以上, 如ク Melanophoren二對シテCocain，0,01 $\mathrm{mg}$ 對 $10 \mathrm{~g}$ 八始ド影響子及ボサ、゙ ルカ或ハ極メテ輕微ナル收縮作用子認メタリ。而シテ $0,1 \mathrm{mg}$ 對 $10 \mathrm{~g}=テ ハ$ 稍々著明二, $1,0 \mathrm{mg}$ 對 $10 \mathrm{~g}$ 二テハ全ク收縮的二作用スルタ認メタリ。向大量， $2,0 \mathrm{mg}$ 對 $10 \mathrm{~g}=$ 二小痘 攀ト共二完全ナル收維作用タ有スルタ認メタリ。

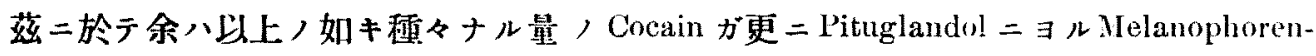

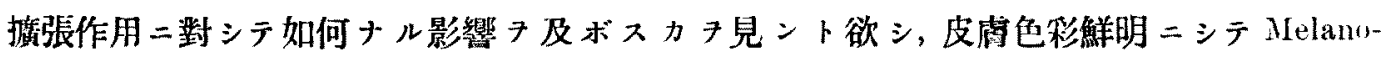
phoren 球形ナル標本ニツキPituglandol $(0,03 \mathrm{ccm}$ 對 $10 \mathrm{~g})$ 注射直後枆々ナル量，Cocain

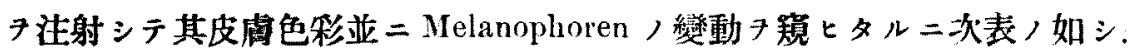




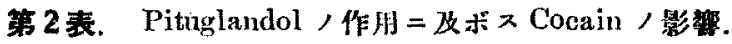

\begin{tabular}{|c|c|c|c|c|c|c|c|c|c|c|c|c|c|c|c|}
\hline \multirow{3}{*}{ 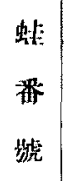 } & \multirow{3}{*}{$\begin{array}{l}\text { 鱛 } \\
\text { 重 } \\
(\mathrm{g})\end{array}$} & \multirow{3}{*}{$\begin{array}{c}\text { 汢射督 } \\
\left(\begin{array}{c}\text { 對 } 10 \mathrm{~g} \\
\mathrm{mg}\end{array}\right)\end{array}$} & \multicolumn{13}{|c|}{ Melanophoren／形狀及ビ皮袖色彩 } \\
\hline & & & \multirow{2}{*}{$\begin{array}{l}\text { 捛 } \\
\text { 射 } \\
\text { 前 }\end{array}$} & \multicolumn{5}{|r|}{ 注 } & \multicolumn{2}{|c|}{ 射 } & \multicolumn{2}{|l|}{ 後 } & \multirow[b]{2}{*}{$2 "$} & \multirow[b]{2}{*}{$3 "$} & \multirow[b]{2}{*}{$4 "$} \\
\hline & & & & 1/12時 & $1 / 6 "$ & $1 / 4 "$ & $1 / 3$ & $5 / 12$ & $1 / 2 n$ & $2 / 3 n$ & $5 / 6$ & 1, & & & \\
\hline 1 & 13 & & - & +1 & + & $H$ & $H$ & H & \# & H & $H$ & $t$ & t & t & 車 \\
\hline$\underline{2}$ & 10 & Pitug. & 一 & $t$ & + & $H$ & $H$ & $H$ & $H$ & $H$ & H & 州 & H & $\#$ & Iftt \\
\hline 3 & 15 & & 一 & + & + & + & + & H & H & $H$ & Ht & Ht & Ht & H & $H$ \\
\hline 4 & 14 & Pitug. & 一 & + & + & $H$ & $H$ & $H$ & $H$ & H & $H$ & $H$ & 世 & $H$ & $H$ \\
\hline 5 & 12 & & - & + & + & + & + & H & $H$ & tft & $H$ & Ht & $H$ & 卅 & $H$ \\
\hline 6 & 10 & & - & + & + & $t$ & + & t & $H$ & $H$ & $H$ & H & \# & H & $H$ \\
\hline 7 & 13 & & - & - & - & + & + & + & + & + & + & + & + & + & + \\
\hline 8 & 15 & Pitıg. & - & - & + & + & $t$ & + & + & + & + & + & + & + & + \\
\hline 9 & 13 & + & - & - & - & + & + & + & $H$ & $\neq$ & $H$ & $H$ & H & $H$ & $H$ \\
\hline 10 & 12 & C. $(0,1)$ & - & - & + & + & + & + & + & + & + & + & + & + & + \\
\hline 11 & 14 & & - & - & - & $t$ & + & + & + & $H$ & $H$ & H & H & $H$ & $H$ \\
\hline 12 & 16 & & - & - & - & - & - & 一 & - & - & - & - & - & - & - \\
\hline 13 & 15 & Pitng. & - & - & - & - & - & - & - & - & - & + & + & + & + \\
\hline 14 & 14 & & - & - & - & - & - & 一 & - & - & - & - & - & + & + \\
\hline 15 & 13 & C. & - & - & - & 一 & - & - & - & - & - & - & - & - & + \\
\hline 16 & 15 & & - & - & - & - & - & - & - & - & - & - & - & - & + \\
\hline
\end{tabular}

注意: C: Cocain, Pitng: Pituglandol $0,03 \mathrm{ccm}$ 嶫 $10 \mathrm{~g}$.

第 2 裴二示ス如ク Pituglandol $(0,03 \mathrm{ccm}$ 劉 $10 \mathrm{~g}) 7$ 單獨二注射七ル場今心注射前球形 ナリシ Melanophoren 八注射5分後ニシテ何レモ稍々振張シテ短突起星狀トナリ, 次デ15一

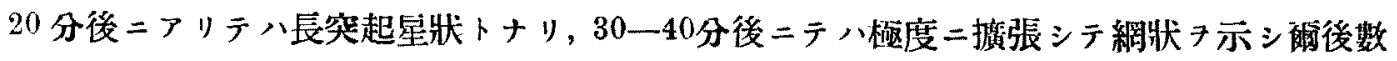

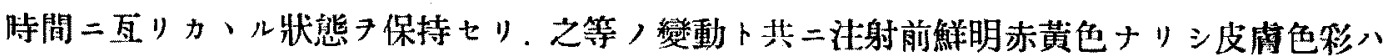
極度二着色シテ晤黑赤色トナレリ。 今 Pituglandol 法射直俊 Cocain $0,01 \mathrm{mg}$ 對 $10 \mathrm{~g} 7$ 注射 スル二注射前球形ナリシ Melanophoren 八注射 5 分後ニシテ何レモ稍々掂張シテ短突起星狀 トナリ, 15-25分後ニシテ更二長突起星狀トナリ, 40分後ニシテ共二極度二摭張シテ網狀卜

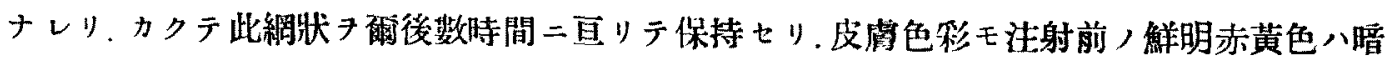

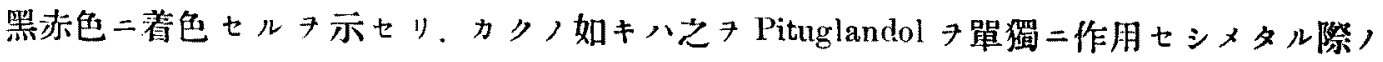

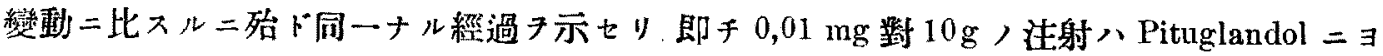
ル Melanophoren-掂張作用二對シテ殆ト影響ヌ及ボサ、゙リシタ認メタリ、次二 Pituglandol 法射直後 Cocain $0,1 \mathrm{mg}$ 對 $10 \mathrm{~g} \rightarrow$ 注射スル二注射前球形ナリシ Melanophoren 八注射 5 分後

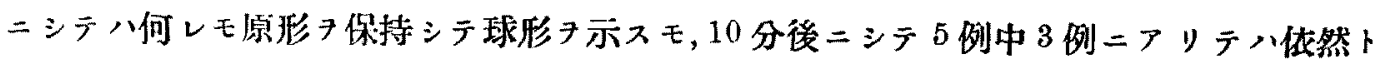
シテ球形タ保持シ他，2例ニアリテ八稍々攄張シテ短突起星狀ョ示セリ.カクテ15 分後ニ テ八何レモ同榡二短突起星狀 $テ$ 示シ5例中3例八此狀態 7 數時間二亘リテ保持七ルモ他ノ2 


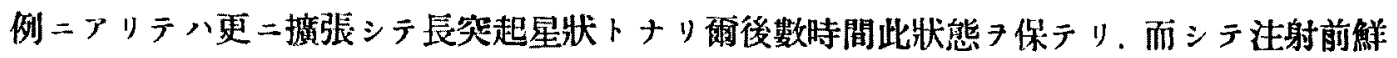

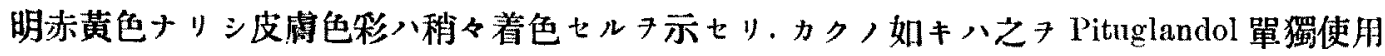
，際二於々ル變動二比較スル二其Melanophoren，擴張度輕微二シテ極度二擴張セリト思 ハル、時期ニアリテモ台長突起星状二止ル Pituglandol $ニ ヨ ル$ Melanophoren-㨽張作用二對シテ稍々著明二抑制的二作用スルタ認メタ

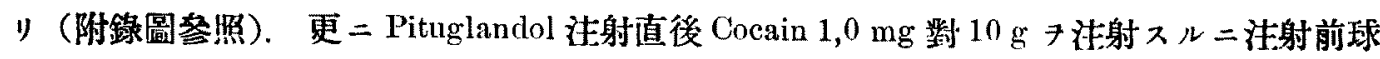
形ナリシ Melanophoren 八注射媵依然トシテ原形フ保持シテ球形 フ示スモ5例中 1 例ニテ リテハ 1 時間後ニシテ稍々擴散つ徵キ示シテ短突起星状トナリ他，4例ハ3-4 時間後二

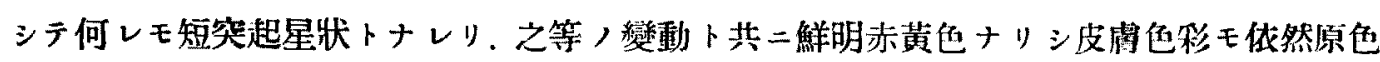
ヨ保持シテ着色ノ徵タ認メザリキ。

斯ノ如キハ之 Pituglandol 7 單獨二注射セル際，變動二比スルニ殆ト Melanophoren ノ擴張八認ムル能ハズ. 即千 Cocain $1,0 \mathrm{mg}$ 對 $10 \mathrm{~g}$ ，注射ハPituglandol 二ヨルMelanophoren拱張作用二對シテ殆ド全ク抑制的二作用スルタ認メタリ。

以上ノ如 ク Pituglandol $(0,03 \mathrm{ccm}$ 對 $10 \mathrm{~g})=\exists ル$ Melanophoren-掂張作月二對 シテ Cocain 0,01 mg 對 $10 \mathrm{~g}$ 八㱠ド影響丹及ボサ、゙ルモ, $0,1 \mathrm{mg}$ 對 $10 \mathrm{~g}$ 八稍々著明二, $1,0 \mathrm{mg}$ 對 $10 \mathrm{~g}$ 八殆ド全ク抑制的二作用スルタ認メタリ.

\section{Tutocain}

今 Tutocain / 程々ナル量 タ皮膚色移暗黑赤色ニシテ Melanophoren 網狀ナル標本ニッ キ注射シテ其皮䖉色柇业二Melanophoren, 變動尹筧ヒタルニ次表ノ如シ。

第3 表. Tutocain $=\Xi$ 几㣀驗.

\begin{tabular}{|c|c|c|c|c|c|c|c|c|c|c|c|c|c|c|c|}
\hline \multirow{3}{*}{$\begin{array}{l}\text { 蛙 } \\
\text { 番 } \\
\text { 號 }\end{array}$} & \multirow{3}{*}{$\begin{array}{l}\text { 體 } \\
\text { 重 } \\
\text { (g) }\end{array}$} & \multirow{3}{*}{$\begin{array}{c}\text { 注射量 } \\
\left(\begin{array}{c}\text { 轰 } 10 \mathrm{~g} \\
\mathrm{mg}\end{array}\right)\end{array}$} & \multicolumn{13}{|c|}{ Melanophoren，形狀並 =皮府色移 } \\
\hline & & & \multirow{2}{*}{$\begin{array}{l}\text { 洼 } \\
\text { 射 } \\
\text { 前 }\end{array}$} & \multicolumn{5}{|r|}{ 注 } & \multicolumn{2}{|c|}{ 射 } & \multicolumn{3}{|l|}{ 挠 } & \multirow[b]{2}{*}{$3 n$} & \multirow[b]{2}{*}{$4 "$} \\
\hline & & & & $1 / 12$ 時 & $1 / 6$, & $1 / 4$, & $1 / 3$ & $5 / 12$ & $1 / 2 "$ & $2 / 3 "$ & $5 / 6$ & $1 "$ & $2 "$ & & \\
\hline 1 & 13 & & Ht & H & H & $H$ & $H$ & HI & H & H & Ht & H & H & H: & Ht. \\
\hline 2 & 11 & 0,01 & tft & tH & Htt & $H$ & Ht & $H$ & $H$ & Ht & H & $H$ & $H$ & H & $H$ \\
\hline 3 & 9 & & Htt & H & $H$ & Ht & H & 卅 & Ht & H & HH & H & \# & 7 & $H$ \\
\hline 4 & 10 & & $H$ & $H$ & $H$ & $\#$ & $H$ & t & 1 & + & + & + & + & + & + \\
\hline 5 & 14 & 0,1 & $H$ & $H$ & $H$ & $H$ & + & + & + & + & + & + & + & $t$ & + \\
\hline 6 & 12 & & H & $H$ & $H$ & -4 & $H$ & $H$ & $H$ & $H$ & $H$ & $H$ & $H$ & $H$ & $\#$ \\
\hline 7 & 11 & & \# & $H$ & $H$ & $H$ & + & + & + & + & - & - & - & + & + \\
\hline 8 & 14 & & HH & $H$ & $H$ & + & + & - & - & - & - & - & - & - & - \\
\hline 9 & 10 & 1,0 & H & $H$ & $H$ & + & + & + & - & - & - & - & - & - & - \\
\hline 10 & 11 & & H & $H$ & + & + & + & - & - & - & - & - & - & - & + \\
\hline 11 & 12 & & Ht & $H$ & $H$ & + & + & + & - & - & - & - & 一 & - & - \\
\hline
\end{tabular}




\begin{tabular}{|c|c|c|c|c|c|c|c|c|c|c|c|c|c|c|c|}
\hline \multirow{3}{*}{ 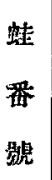 } & \multirow{3}{*}{$\begin{array}{l}\text { 體 } \\
\\
\text { 重 } \\
(\mathrm{g})\end{array}$} & \multirow{3}{*}{$\begin{array}{c}\text { 注射量 } \\
\left(\begin{array}{c}\text { 對 } 10 \mathrm{~g} \\
\mathrm{mg}\end{array}\right)\end{array}$} & \multicolumn{13}{|c|}{ Melanophoren，形狀並=皮笛色移 } \\
\hline & & & \multirow{2}{*}{$\begin{array}{l}\text { 洼 } \\
\text { 射 } \\
\text { 前 }\end{array}$} & \multicolumn{5}{|r|}{ 洼 } & \multicolumn{2}{|c|}{ 射 } & \multicolumn{3}{|l|}{ 後 } & \multirow[b]{2}{*}{$3 "$} & \multirow[b]{2}{*}{$4 ”$} \\
\hline & & & & $1 / 12$ 時 & $1 / 6 ”$ & $1 / 4 "$ & $1 / 3 n$ & $5 / 12$ & $1 / 2 "$ & $2 / 3 n$ & $5 / 6 "$ & $1 "$ & $2 \cdots$ & & \\
\hline 12 & 14 & & H: & $H$ & H & + & $t$ & - & - & - & - & - & - & - & + \\
\hline 13 & 15 & 2,0 & Ht & H & $H$ & + & + & - & - & - & - & 一 & - & - & - \\
\hline 14 & 13 & & $H$ & $H$ & + & $+r$ & - & - & - & - & - & - & - & + & + \\
\hline
\end{tabular}

第 3 表二示ス如ク $0,01 \mathrm{mg}$ 對 $10 \mathrm{~g}$ ニアリテハ注射前絧狀ナリシ Melanophoren 八注射媵

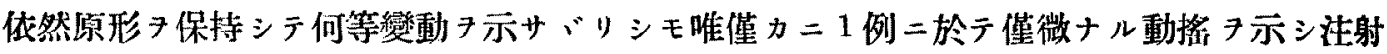

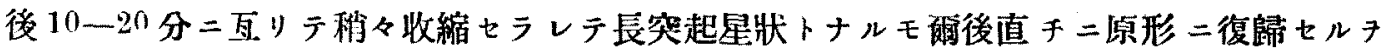

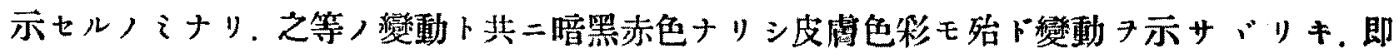
チ $0,01 \mathrm{mg}$ 對 $10 \mathrm{~g}$ ，注射ニテリテハMelanophoren，上二殆ド變動 與へザルカ或八極

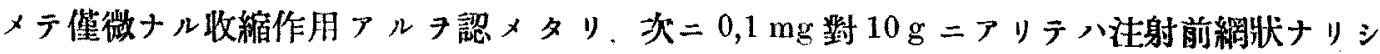
Melanophoren 八注射 5 分後ニシテ 3 例中 2 例八原形 7 保持シテ網状 7 示スモ他ノ1例八 稍々收縮せラレテ長突起星狀トナリ 10 分後ニテハ何レモ長突起星狀タ示セリ.斯クテ 3 例 中 1 例八爾後數時間二互リテ現狀 保持スルモ他，2例八更二收縮七ラレテ短突杷星狀卜

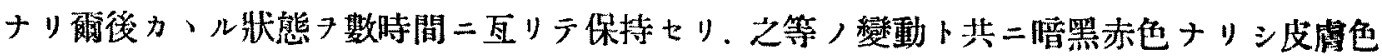

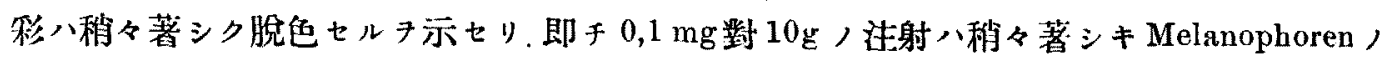
收縮 フ來ス 認メタリ. 更二 $1,0 \mathrm{mg}$ 䍌 $10 \mathrm{~g}$ ノ注射ニアリテハ注射前網狀ナリシ Melanophoren ハ5 分後ニシテ何レモ稍, 收縮セラレテ骎突起星状トナリ, 10-20分後ニシテ更二 短突赸星狀トナリ, 次デ 20-30 分後ニシテハ何レモ極度二收縮セラレテ球狀トナリ爾後數

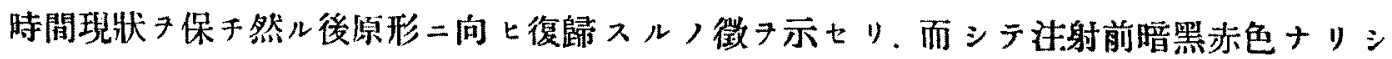

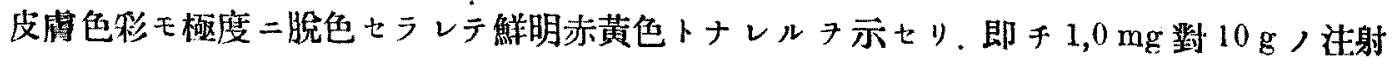
八 Melanophoren 7全ク收縮七シムルチ認メタリ。尚大量, $2,0 \mathrm{mg}$ 数 $10 \mathrm{~g}$ ，注射二アリ テハ殆ド $1,0 \mathrm{mg}$ 對 $10 \mathrm{~g}$ ，際，變動ト同一ナル經過タ示シ注射前網狀ナリシ Melanophoren 八完全二收縮シ之等，變動二件七皮虚色移モ極度二脫色セルタ示セリ. 蓋シ其等，變動

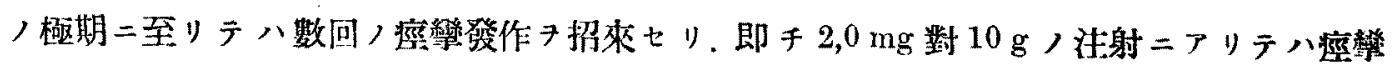
ト共二 Melanophoren，完全ナル收縮ヨ來スフ認メタリ。

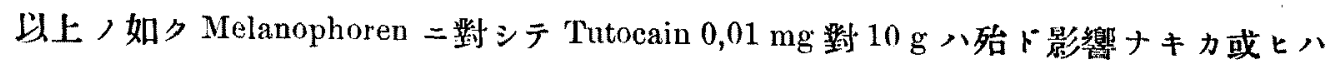
極メテ僅微ナル收維作用キ示スモ， $0,1 \mathrm{mg}$ 對 $10 \mathrm{~g}$ 二テハ稍々著明二, $1,0 \mathrm{mg}$ 對 $10 \mathrm{~g}$ 二テハ

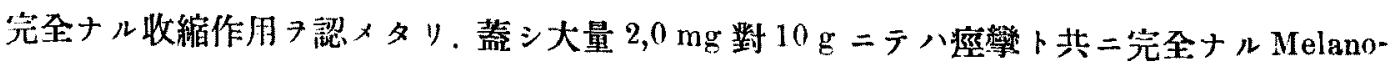
phoren，收縮作用7認メタリ。

茲二於テ余ハ上上, 如キ種々ナル量, Tutocain ガ Pituglandol ニョル Melanophoren-搌 張作用二對シテ如何ナル影響キ及ボスカ 
phoren 球形ナル標本ニツキ Pituglandol $(0,03 \mathrm{ccm}$ 對 $10 \mathrm{~g})$ 注射直後程々ナル量，Tutocain

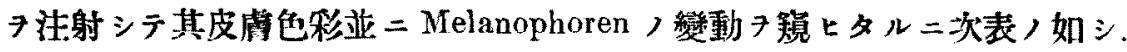

苐 4 表. Pituglandol，作用二及ボス Tutocain，影警。

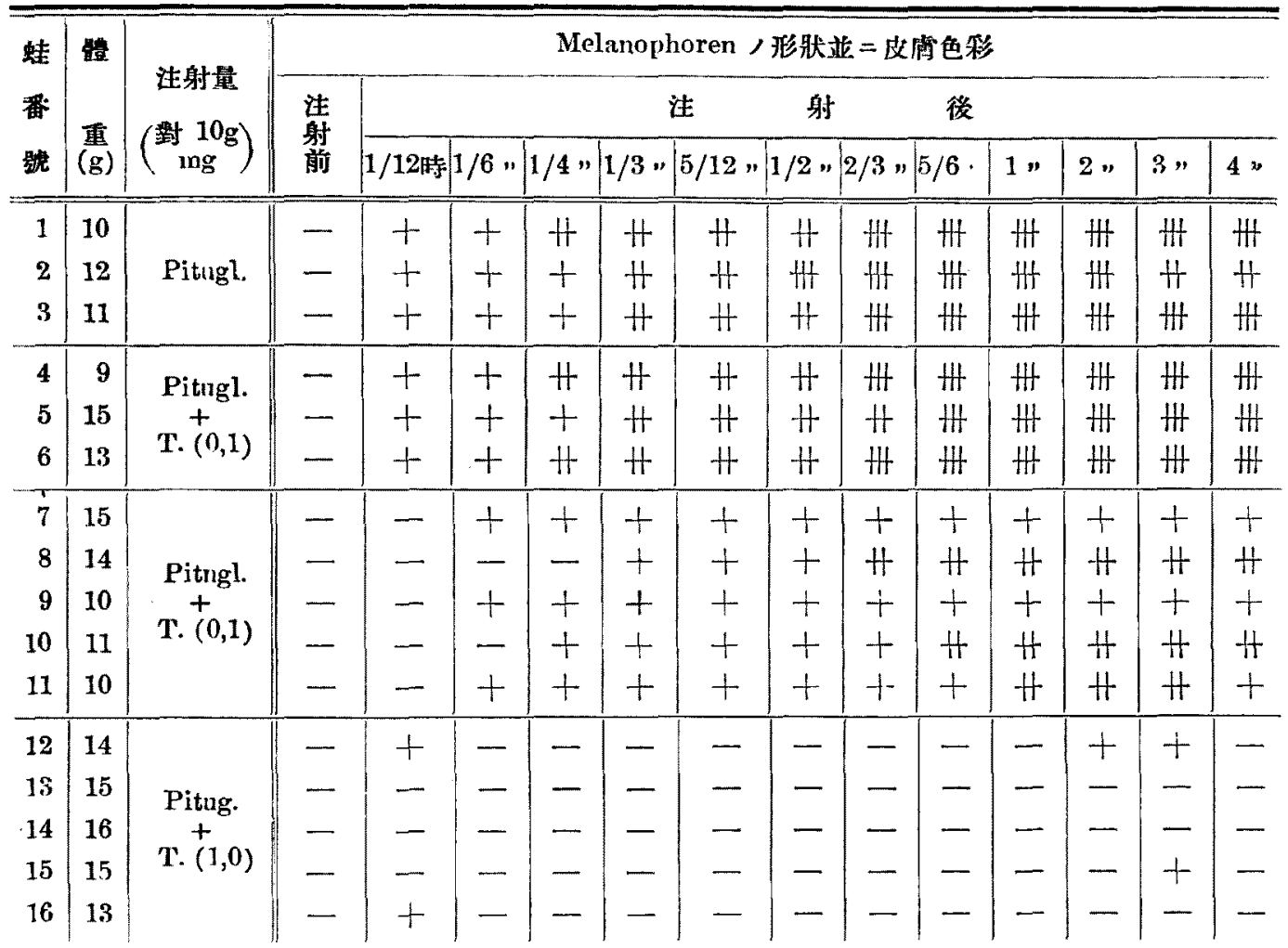

注意：T: Tutocain, Pitugl: Pituglandol $0,03 \mathrm{ccm}$ 䍌 $10 \mathrm{~g}$ 各適用.

第 4 表二示ス如ク Pituglandol $(0,03 \mathrm{~cm}$ 對 $10 \mathrm{~g})$ フ單獨二作用セシメタル際ハ球形ナ リシ Melanophoren 八注射 5 分後ニシテ短突赸星状トナリ, 15-20分後ニシテ長突起星狀卜 ナリ, 次デ 30-40 分後ニシテ極度二擴張シテ網狀トナレリ. 斯クラ注射前鮮明赤黃色ナリ シ皮席色彩乇極度二着色シテ暗黑赤色二着色セルタ示セリ．今 Pituglandol 注射直後 Tutocain $0,01 \mathrm{mg}$ 對 $10 \mathrm{~g}$ ) 注射ニアリテハ注射前球形ナリシ Melanophoren 八注射 5 分後ニシ テ何レモ短突起星狀トナリ15-20分ニシテ無突起星狀, 次デ 40-50分後ニシテ何レモ完 全二捇張シテ網狀子示セり. 斯クテ鮮明赤黃色ナリシ皮膚色移モ極度二着色セラレテ暗黑 赤色トナレリ、斯クノ如キハPituglandol 單獨ノ際ノ變動ト殆ド同一ナル Melanophoren ノ擴張狀態 示スモノニシテ之二因り テ Tutocain $0,01 \mathrm{mg}$ 對 $10 \mathrm{~g}$ 八Pituglandol $=\exists ル$

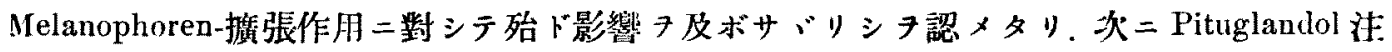
射直後 Tutocain $0,1 \mathrm{mg}$ 践 $10 \mathrm{~g} 7$ 注射スル二拄射前球形ナリシ Melanophoren 八注射 5 分後

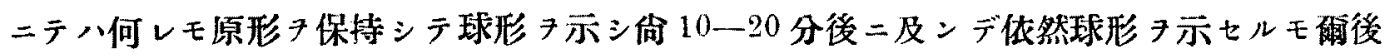
䄸せ擴張セラレテ, $15-25$ 分後ニシテハ何レモ短突起星狀 示セり. 斯クテ 5 例中 3 例八爾 


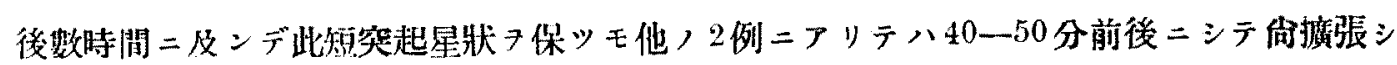
テ長突起星状トナレリ・而シテ解明赤黄色ナリシ皮或色移モ稍々着色セルタ示セリ・斯ノ如

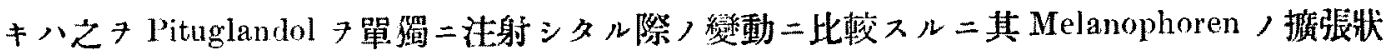

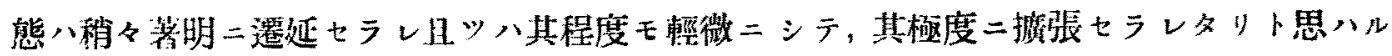

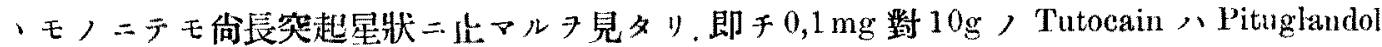

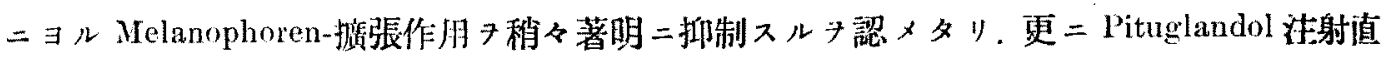
後 $1,0 \mathrm{mg}$ 跱 $10 \mathrm{~g}$ ，Tutocain 7 让射スル二法射前球形ナりシ Melanophoren，注射 5 分後二

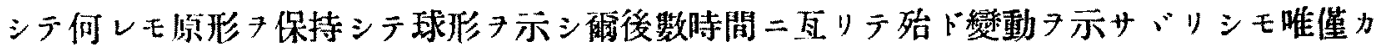
ニ 變動尹示サ、リキ.斯ク，如キハ之キ Pituglandol 7 單獨二作用セシメタル際ノ變動二比較

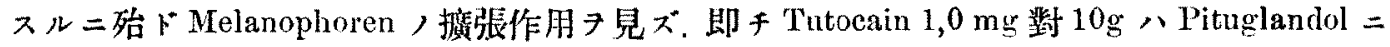
ヨルMelanophoren-擴張作用二對シテ始ド金ク抑制的二作用スルタ諰メタリ。

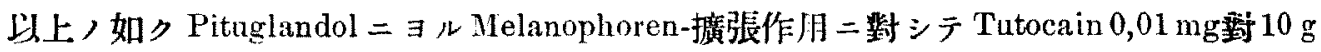

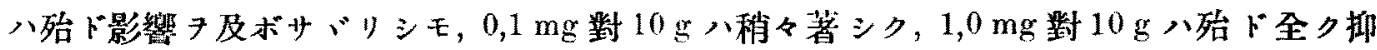
制的二作朋スルタ認メタリ。

\section{Pantocain}

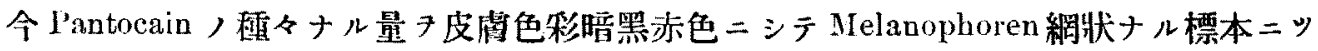
キ注射シテ其皮膚色彩韭二Melanophoren，變動フ筑七タル二次表ノ如シ。

第 5 表. Pantocain $=3$ 几餵驗。

\begin{tabular}{|c|c|c|c|c|c|c|c|c|c|c|c|c|c|c|c|}
\hline \multirow{3}{*}{ 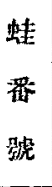 } & \multirow{3}{*}{$\begin{array}{l}\text { 筁 } \\
\text { (g) } \\
\text { 重 }\end{array}$} & \multirow{3}{*}{$\begin{array}{c}\text { 注射量 } \\
\left(\begin{array}{c}\text { 對 } 10 \mathrm{~g} \\
\mathrm{mg}\end{array}\right)\end{array}$} & \multicolumn{13}{|c|}{ 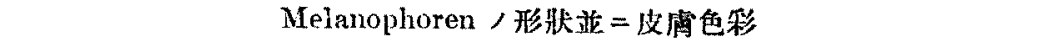 } \\
\hline & & & \multirow{2}{*}{$\begin{array}{l}\text { 法 } \\
\text { 射 } \\
\text { 前 }\end{array}$} & \multicolumn{5}{|r|}{ 注 } & \multicolumn{2}{|c|}{ 射 } & \multicolumn{3}{|l|}{ 啳 } & & \\
\hline & & & & $1 / 12$ 時 & $1 / 6 "$ & $1 / 4$ & $1 / 3$ & $\mid 5 / 12$, & $1 / 2 »$ & $2 / 3$ & $5 / 6$ & $1 "$ & $2 "$ & $3 n$ & $4 *$ \\
\hline $\begin{array}{l}1 \\
2 \\
3\end{array}$ & $\begin{array}{l}10 \\
11 \\
14 \\
\end{array}$ & 0,01 & $\begin{array}{l}H \\
H \\
H\end{array}$ & $\begin{array}{l}H \\
H \\
H \\
H\end{array}$ & $\begin{array}{l}H \\
H \\
H\end{array}$ & $\begin{array}{l}H \\
H \\
H\end{array}$ & $\begin{array}{l}\text { Ht } \\
\text { Ht } \\
\text { Ht }\end{array}$ & $\begin{array}{l}\text { HI } \\
\text { Ht } \\
+H\end{array}$ & $\begin{array}{l}H \\
H \\
H\end{array}$ & $\begin{array}{l}H+H \\
H \\
H\end{array}$ & $\begin{array}{l}\text { Ht } \\
\text { Ht } \\
\text { it }\end{array}$ & $\begin{array}{l}H \\
+H \\
H t\end{array}$ & $\begin{array}{l}H \\
H \\
H\end{array}$ & $\begin{array}{l}H \\
H \\
H\end{array}$ & $\begin{array}{l}\text { H } \\
H \\
H\end{array}$ \\
\hline $\begin{array}{l}4 \\
5 \\
6 \\
\end{array}$ & $\begin{array}{l}15 \\
14 \\
13 \\
\end{array}$ & 0,05 & $\begin{array}{l}\text { H } \\
\text { H } \\
\text { Ht }\end{array}$ & $\begin{array}{l}\text { H } \\
\text { II } \\
+1\end{array}$ & $\begin{array}{l}H \\
H \\
H\end{array}$ & $\begin{array}{l}H \\
H \\
H\end{array}$ & $\begin{array}{l}H \\
H \\
H\end{array}$ & $\begin{array}{l}+ \\
+ \\
+\end{array}$ & $\begin{array}{l}+ \\
+ \\
+\end{array}$ & $\begin{array}{l}+ \\
H \\
+\end{array}$ & $\begin{array}{l}+ \\
4 \\
+\end{array}$ & $\begin{array}{l}+ \\
H \\
+\end{array}$ & $\begin{array}{l}+ \\
+ \\
+\end{array}$ & $\begin{array}{l}+ \\
+ \\
+\end{array}$ & $\begin{array}{l}+1 \\
+1 \\
+\end{array}$ \\
\hline $\begin{array}{r}7 \\
8 \\
9 \\
10 \\
11\end{array}$ & $\begin{array}{r}15 \\
9 \\
16 \\
12 \\
13\end{array}$ & 0,2 & $\begin{array}{l}\text { Ht } \\
\text { H } \\
\text { Ht } \\
H \\
H\end{array}$ & $\begin{array}{l}H \\
H \\
H \\
H \\
H\end{array}$ & $\begin{array}{l}H \\
+ \\
H \\
H \\
H\end{array}$ & $\begin{array}{l}+ \\
+ \\
+ \\
+1 \\
+\end{array}$ & $\begin{array}{l}+ \\
+ \\
+ \\
+ \\
+\end{array}$ & $\begin{array}{l}- \\
- \\
+ \\
-\end{array}$ & $\begin{array}{l}- \\
- \\
- \\
-\end{array}$ & $\begin{array}{l}- \\
- \\
-\end{array}$ & $\begin{array}{l}- \\
- \\
- \\
-\end{array}$ & $\begin{array}{l}- \\
- \\
-\end{array}$ & $\begin{array}{l}- \\
- \\
- \\
-\end{array}$ & $\frac{-}{-}$ & $\begin{array}{l}+ \\
- \\
+ \\
+\end{array}$ \\
\hline $\begin{array}{l}12 \\
13 \\
14\end{array}$ & $\begin{array}{l}14 \\
15 \\
15\end{array}$ & 0,5 & $\begin{array}{l}H \\
H \\
H\end{array}$ & $\begin{array}{l}H \\
H \\
H\end{array}$ & $\begin{array}{l}+ \\
+ \\
+\end{array}$ & $\begin{array}{l}t \\
t \\
t\end{array}$ & $\begin{array}{c}- \\
+ \\
-\end{array}$ & $\frac{-}{-}$ & $\begin{array}{l}- \\
-\end{array}$ & $\begin{array}{l}- \\
-\end{array}$ & $\frac{-}{-}$ & $\begin{array}{l}- \\
- \\
-\end{array}$ & $\begin{array}{l}- \\
- \\
-\end{array}$ & $\begin{array}{l}- \\
- \\
-\end{array}$ & - \\
\hline
\end{tabular}


第 5 表二示ス如ク $0,01 \mathrm{mg}$ 對 $10 \mathrm{~g}$ ニアリテハ迬射前網狀ナリシ Melanophoren 八依然

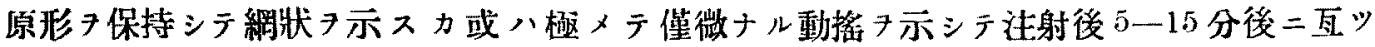
テ稍々收縮シテ長突起星狀トナルノミナリ、斯クテ暗黑赤色ナリシ皮膚色移モ殆ド變動 示サ、゙リキ。即キ 0,01 mg 對 $10 \mathrm{~g} /$ Pantocain ハ Melanophoren二對シテ殆ド影響キ及ボ

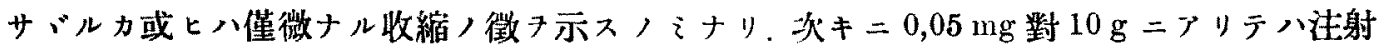
前網狀ナリシ Melanophoren 八注射 5 分後ニシテハ3 例中 1 例ニアリテ原形キ保持シテ網 狀 示スモ他, 2 例ニアリテハ稍々收縮シテ長突起星狀タ示セリ. 而シテ10分後ニテハ何 レモ稍々收縮シテ長突起星狀丹示シ3 例中 1 例ニアリテ八爾後数時間二互リ此狀態 7 保持 セリ，他ノ 2 例ニアリテハ更二收縮シテ短哭起星狀トナリ斯クテ數時間タ經過セリ，又暗黑 赤色ナリシ皮虚色移モ稍々著シク脫色セラレシタ示セり.即チ $0,05 \mathrm{mg}$ 對 $10 \mathrm{~g}$, Pantocain

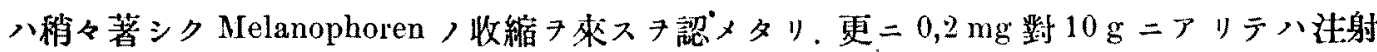
前網狀ナリシ Melanophoren ハ5 分後ニシテ何レモ稍々收縮，徵フ示シテ長突起星狀トナ .1，10-20 分後ニシテ更二收縮，度尹强メテ短突起星狀小ナリ，20-30 分後二テ八極度二 收縮シテ球狀トナリ爾後數時間二互リテ現狀ヲ保持セり．之等，變動二伴七注射前暗黑赤 色ナリシ皮咸色稿八極度二脫色七ラレテ鮮明赤黃色トナレリ．即千 $0,2 \mathrm{mg}$ 對 $10 \mathrm{~g} /$ Pantocain M Melanophoren，完全ナル收縮作用子認メタ・.向大量, $0,5 \mathrm{mg}$ 對 $10 \mathrm{~g}$ ノ際ニフリ テハ $0,2 \mathrm{mg}$ 對 $10 \mathrm{~g}$ ，際＼cjkstart變動卜砝ド同一ナル經過タ示シ注射前網狀ナリシ Melanophoren 八完全二收縮シテ球狀トナリ暗黑赤色ナリシ皮虚色彩ハ極度二脫色セラレテ鮮明赤黄色门 ナレリ。而シテ之等ノ變動ノ極期ニアリテハ何レノ蛙モ外來ノ刺戟ニヨリテ容易二㽷彎發

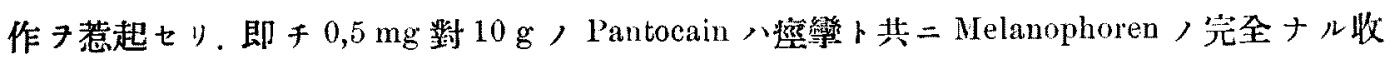
維フ來スフ認メタリ。

以上ノ如ク Melanophoren 二對シテ Pantocain 0,01 $\mathrm{mg}$ 對 $10 \mathrm{~g}$ ハ名ド影響キ及ボサ、゙ル

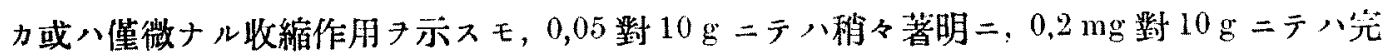

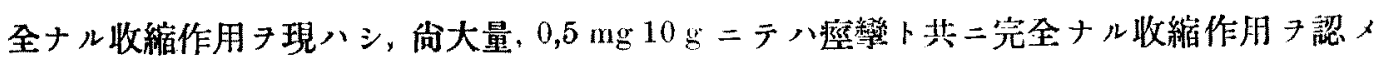
タリ。

茲二於テ余以上ノ如キ種々ナル量，Pantocain ガ更二Pituglandol二ヨル Melano-

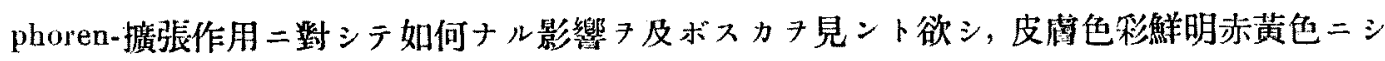

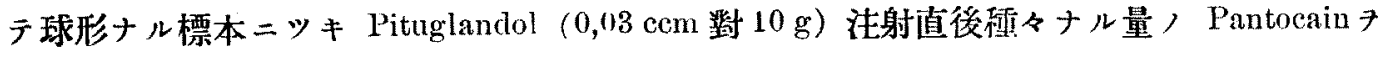
注射シテ其皮虚色移亚二Melanophoren，變動キ窺ヒタル二次表ノ如シ. 


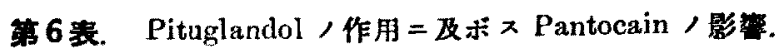

\begin{tabular}{|c|c|c|c|c|c|c|c|c|c|c|c|c|c|c|c|}
\hline \multirow{3}{*}{$\begin{array}{l}\text { 蛙 } \\
\text { 番 } \\
\text { 號 }\end{array}$} & \multirow{3}{*}{$\begin{array}{l}\text { 體 } \\
\\
\text { (g) } \\
\text { (g) }\end{array}$} & \multirow{3}{*}{$\begin{array}{c}\text { 注射蹱 } \\
\left(\begin{array}{c}10 \mathrm{~g} \\
\mathrm{mg}\end{array}\right)\end{array}$} & \multicolumn{13}{|c|}{ Melanophoren /形狀区ビ皮觔色移 } \\
\hline & & & \multirow{2}{*}{$\begin{array}{l}\text { 洼 } \\
\text { 射 } \\
\text { 前 }\end{array}$} & \multicolumn{5}{|r|}{ 洼 } & \multicolumn{2}{|c|}{ 射 } & \multicolumn{2}{|l|}{ 後 } & \multirow[b]{2}{*}{$2 n$} & \multirow[b]{2}{*}{$3 ”$} & \multirow[b]{2}{*}{$4 n$} \\
\hline & & & & $1 / 12$ 時 & $1 / 6 "$ & $1 / 4$ & $1 / 3$ & $5 / 12$ & $1 / 2$ & $2 / 3$ & $5 / 6 n$ & $1 "$ & & & \\
\hline 1 & 11 & & - & + & t & $H$ & th & $H$ & H & H & $H$ & Ht & $H t$ & 冊 & m \\
\hline 2 & 12 & Pitugl. & - & -+ & + & + & H & $H$ & Ht & $H$ & H & H & $H$ & $t$ & H \\
\hline 3 & 10 & & - & + & + & + & $H$ & $H$ & $H$ & $H$ & $H$ & H & H & H & H \\
\hline 4 & 11 & Pitugl. & - & + & + & + & H & $H$ & $H$ & HH & H & \# & H & t & \# \\
\hline 5 & 13 & . & - & + & + & + & $H$ & $\#$ & $H$ & $H$ & III & H & H & 卅 & $\mathbb{H}$ \\
\hline 6 & 14 & & - & + & $t$ & + & + & $H$ & $H$ & H & HH & HI & H & $\mathrm{HH}$ & $\mathbb{H}$ \\
\hline 7 & 12 & & - & - & - & + & + & + & + & + & $H$ & $H$ & $H$ & $H$ & $t$ \\
\hline 8 & 11 & Pitugl. & - & - & - & - & + & + & + & + & + & + & + & + & + \\
\hline 9 & 12 & 7 & - & - & + & + & + & + & + & $t$ & + & + & + & + & + \\
\hline 10 & 10 & P. $(0,05)$ & - & - & - & - & + & + & + & + & + & + & $t$ & + & + \\
\hline 11 & 16 & & - & - & - & + & + & + & + & + & H & $H$ & $H$ & $H$ & $H$ \\
\hline 12 & 15 & & - & - & - & - & - & - & - & - & - & - & - & - & - \\
\hline 13 & 14 & Pitugl. & - & - & - & - & - & - & - & - & - & - & - & - & - \\
\hline 14 & 13 & 200 & - & + & - & - & - & - & - & - & - & - & - & - & - \\
\hline 15 & 12 & P. $(0,2)$ & - & - & + & - & - & - & - & - & - & - & - & - & + \\
\hline 16 & 11 & & -- & - & - & - & - & - & - & - & - & - & - & - & - \\
\hline
\end{tabular}

法意：P: Pantocain, Pitngl : Pituglandol $0,03 \mathrm{ccm}$ 数 $10 \mathrm{~g}$ 各適用.

第 6 表二示ス如ク Pituglandol $(0,03 \mathrm{ccm}$ 對 $10 \mathrm{~g})$ 7單獨二作用セシメタル際八注射前 球形ナリシ Melanophoren 八注射 5 分後ニシテ何レモ稍々擴張シテ短突起星狀トナリ.15一 20 分後ニシテ更二長突起星狀トナリ，30-40 分後ニシテハ極度二嚽張シテ網状フ示セリ. 斯クテ鮮明赤黃色ナリシ皮虚色移モ注射 30 -40 分後ニシテ極度二者色シテ喓黑赤色 七り。

今 Pituglandol 住射直後 Pantocain $0,01 \mathrm{mg}$ 数 $10 \mathrm{~g} \ni$ 作用セシムル二注射前球形ナリシ Melanophoren，註射5分後ニシテ何レモ短突起星狀キ示シ, $20-25$ 分後ニシテ更二長突起

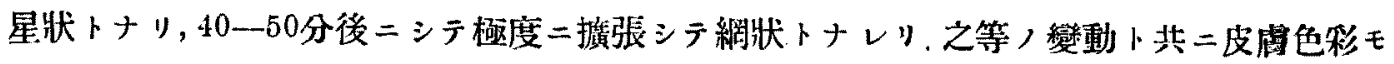

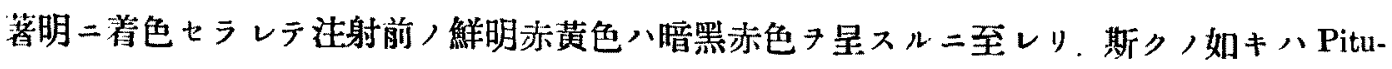
glandol 7 單獨二作用セシメタル際ノ變動ト殆ド同一ナル經過 キ示ス・ヒノニシテ因ッテ

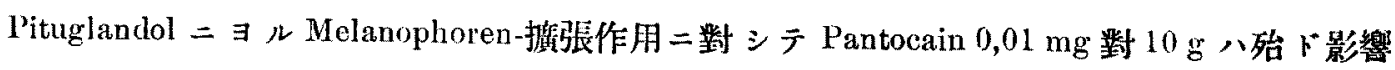
ヨ及ボサザリシタ認メタリ. 次二 Pituglandol 注射值後 Pantocain 0,05 mg 對 $10 \mathrm{~g} 7$ 注射 ル二注射前球形ナリシ Melanophoren，注射後10-20 分二互リテ何レモ原形 7 保持シテ球

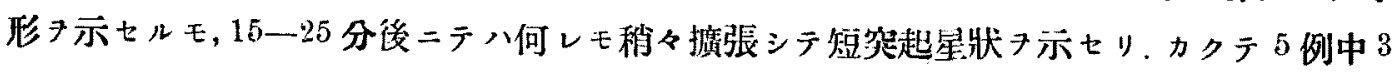

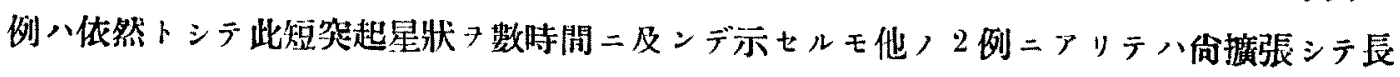




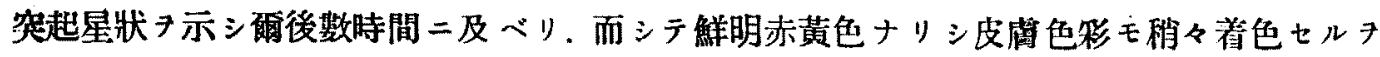
示セリ. 斯ク，如キハPituglandol 注射，際，變動卜比較スル=其 Melanophoren-摝張狀態

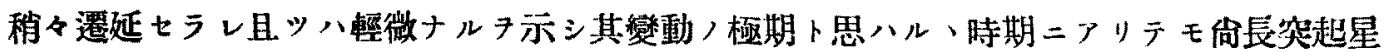
狀二止マレルタ示セり，即手 Pantocain 0,05 mg 對 $10 \mathrm{~g}$ ，注射， Pituglandol =ヨル Melanophoren-振張作用二對シテ稍々落シク抑制的二作用スルタ認メタリ.更二 Pituglandol 注射 直後 Pantocain $0,2 \mathrm{mg}$ 對 $10 \mathrm{~g} 7$ 沬射スルニ注射前球形ナリシ Melanophoren 八俅然球形 7

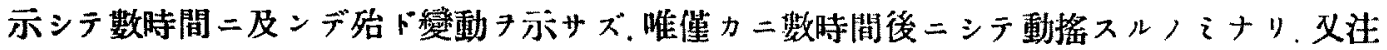

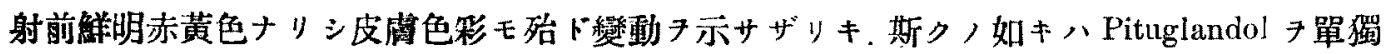

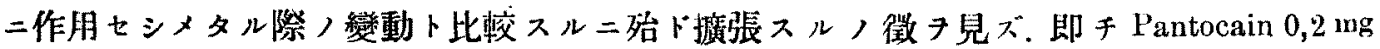
對 $10 \mathrm{~g}$ / 拄射 Pituglandol ニヨル Melanophoren-撗張作用二對シテ殆ド全ク抑制的二作用 スルタ認メタリ。

以上ノ如ク Pituglandol $ニ ョ ル$ Melanophoren-拱張作用二對 シテ Pantocain 0,01 mg 對 $10 \mathrm{~g}$ 八殆ド影響フ及ボサザルモ，0,05 mg 對 $10 \mathrm{~g}$ 八稍々著明二, 0,2 mg 對 $10 \mathrm{~g}$ 八殆ド全ク 抑制的二作用スルタ䍿メタリ。

\section{Novocain}

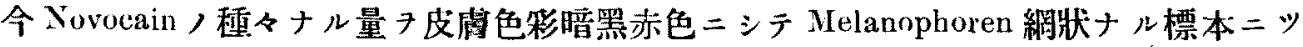

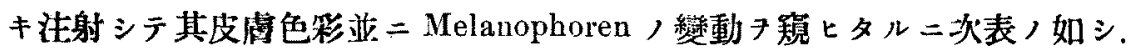

茀7表. Novocain $=\exists 几$ 實醶.

\begin{tabular}{|c|c|c|c|c|c|c|c|c|c|c|c|c|c|c|c|}
\hline \multirow{3}{*}{$\begin{array}{l}\text { 蛙 } \\
\text { 番 } \\
\text { 號 }\end{array}$} & \multirow{3}{*}{$\begin{array}{l}\text { 體 } \\
\text { (g) } \\
\text { ( 重 }\end{array}$} & \multirow{3}{*}{$\begin{array}{c}\text { 注射量 } \\
\left(\begin{array}{c}\text { 對 } 10 \mathrm{~g} \\
\mathrm{mg}\end{array}\right)\end{array}$} & \multicolumn{13}{|c|}{ Melanophoren，形狀並=文学色彩 } \\
\hline & & & \multirow{2}{*}{$\begin{array}{l}\text { 洼 } \\
\text { 射 } \\
\text { 前 }\end{array}$} & \multicolumn{5}{|c|}{ 隹 } & \multicolumn{2}{|c|}{ 射 } & \multicolumn{3}{|l|}{ 後 } & \multirow[b]{2}{*}{$3 "$} & \multirow[b]{2}{*}{$4 "$} \\
\hline & & & & $1 / 12$ 時 & $1 / 6 *$ & $1 / 4 "$ & $1 / 3$ & $5112 "$ & $1 / 2 "$ & $2 / 3 n$ & $5 / 6 \cdots$ & $1 "$ & $2 "$ & & \\
\hline 1 & 15 & \multirow{3}{*}{0,1} & Ht & Hit. & $H$ & $H$ & $H$ & $H$ & $H$ & H & H & Ht & 米 & $H$ & $\mathrm{Ht}$ \\
\hline 2 & 11 & & $H$ & Ht & $H$ & H & $H$ & H & H & $H$ & \# & \# & $H$ & H & H \\
\hline 3 & 10 & & $H$ & H & H & H & H & $H$ & \# & Ht & $H$ & \# & H & Ht & H \\
\hline 4 & 13 & \multirow{3}{*}{0,5} & H & $H$ & H & $H$ & $H$ & $H$ & $H$ & H & H & $H$ & $H$ & H & HH \\
\hline 5 & 12 & & $H$ & H & H & $H$ & + & + & + & + & + & + & + & + & + \\
\hline 6 & 11 & & Ht & H & $H$ & H & + & + & + & + & + & $\div$ & + & + & + \\
\hline 7 & 14 & \multirow{5}{*}{5,0} & Ht & $H$ & $H$ & + & + & + & - & - & - & - & - & - & + \\
\hline 8 & 10 & & Hit & $H$ & $H$ & + & $t$ & - & - & $\ldots$ & - & - & - & - & - \\
\hline 9 & 13 & & $H$ & $H$ & + & $t$ & - & - & - & - & - & - & - & - & - \\
\hline 10 & 10 & & $\mathrm{HI}$ & $H$ & $H$ & $H$ & + & + & - & - & - & - & - & + & + \\
\hline 11 & 13 & & H & $H$ & H & $H$ & + & + & - & - & - & - & - & - & - \\
\hline 12 & 11 & \multirow{3}{*}{10,0} & $H$ & $H$ & + & + & + & - & - & - & - & - & - & - & - \\
\hline 13 & 13 & & H & $H$ & $H$ & + & $t$ & - & - & - & - & - & - & - & - \\
\hline 14 & 15 & & $H$ & H & + & + & + & + & - & - & - & - & - & - & - \\
\hline
\end{tabular}




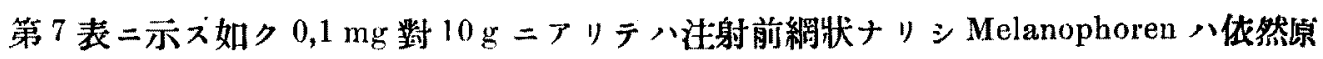

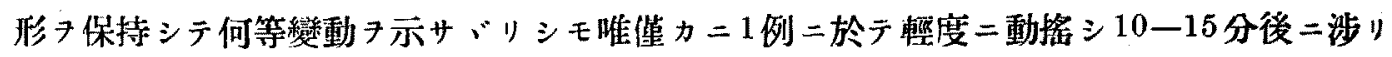
テ稍々收縮シテ長笑起星狀トナルモ爾後直チ二原形二復歸セルタ示セリ．己等ノ變化ト共 二注射前，暗黑赤色ナりシ皮有色彩八依然トシテ保持セラレタリ．即于 $0,1 \mathrm{mg}$ 對 $10 \mathrm{~g}$ ，注 射ハMelanophoren 二對シテ何等變動 7 與へザルカ或ハ僅微ナル收縮作用フ現ハスフ認メ タリ, 次 $=0,5 \mathrm{mg}$ 對 $10 \mathrm{~g}=テ ハ 3$ 例中 1 例ニテリテハ注射 5 分後ニシテミル二短張り原形 保持シテ網狀ォ示シ, 10 分後ニシテ稍々收維シテ長然起星状トナリ爾後 2 恃間二瓦リテ現 形尹保持シ然ル後原形二向ッテ復歸スルチ示七リ，他ノ2例ニアリテハ5分後ニシテ稍々 收縮シテ長突起星狀トナリ，20 分後ニシテ更二收縮シテ短突赸星狀トナリ鲧後數時間二互 リテ此状態ヨ保持セリ、斯クテ腰黑赤色ナリシ皮虚色彩毛稍々著シク脫色セラレタリ、即チ $0,5 \mathrm{mg}$ 對 $10 \mathrm{~g}$ ，Novocain 八榾々著明二Melanophoren タ收縮セシムルタ認メタリ.更二 $=5,0 \mathrm{mg}$

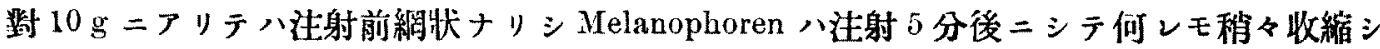
テ長突起星狀トナリ，10-20分後二シテ更二短篹起星狀トナリ，20一-30分後ニシテハ極度 二收縮セラレテ球形フ示セリ。而シテ喓黑赤色ナリシ皮虚色彩七著明二脫色セラレテ何レ モ鮮明赤黃色トナレリ。即千 $5,0 \mathrm{mg}$ 對 $10 \mathrm{~g}$ ，Novocain，完全二Melanophoren，收縮子來

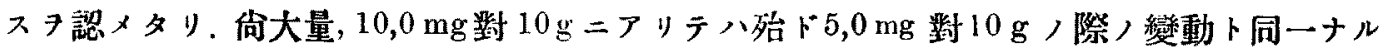
經過 示シ注射前網狀ナりシ Melanophoren 八極度二收縮シテ球版トナリ且ッ䕎黑赤色ナ リシ皮膚色彩八著明二脫色セラレテ鮮明赤黃色トナレリ。蓋シ之等ノ綎動ノ極期卜思ハル

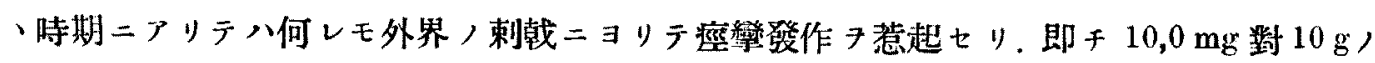

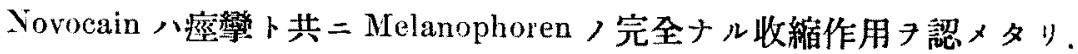

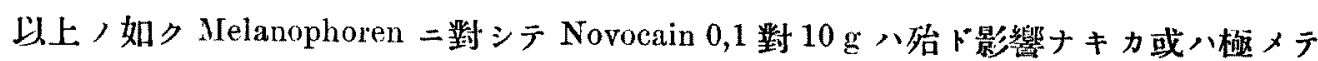
僅微ナル收縮作用ヨ示スモ，0,5 $\mathrm{mg}$ 對 $10 \mathrm{~g}=$ ハ稍々著明二, $5,0 \mathrm{mg}$ 對 $10 \mathrm{~g}$ 二テ ハ完全ナ

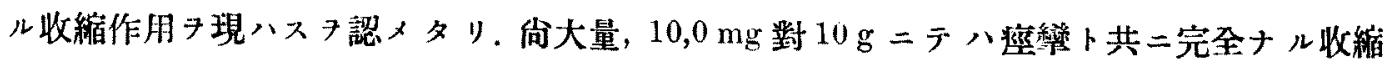
作用タ有スルキ認メタリ。

茲二於テ余ハ以上ノ如租ヶナル量，Novocain ガ更二Pituglandol $=ヨ ル$ Melanopho-

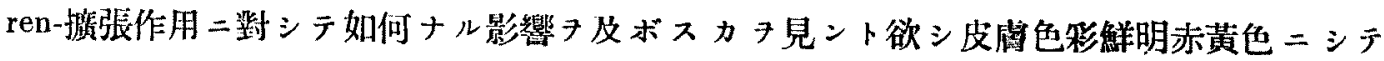
Melanophoren 球形ナル標本ニツキPituglandol $(0,03 \mathrm{ccm}$ 對 $10 \mathrm{~g})$ 注射後極々ナル量，Novo-

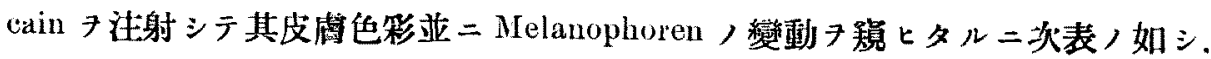




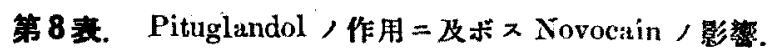

\begin{tabular}{|c|c|c|c|c|c|c|c|c|c|c|c|c|c|c|c|}
\hline \multirow{3}{*}{$\begin{array}{l}\text { 蛙 } \\
\text { 番 } \\
\text { 號 }\end{array}$} & \multirow{3}{*}{$\frac{\text { 嗌 }}{(\mathrm{g})}$} & \multirow{3}{*}{$\begin{array}{c}\text { 注射量 } \\
\left(\begin{array}{c}\text { 数 } 10 \mathrm{~g} \\
\mathrm{mg}\end{array}\right)\end{array}$} & \multicolumn{13}{|c|}{ Melanophoren，形状並 =文福色移 } \\
\hline & & & \multirow{2}{*}{$\begin{array}{l}\text { 声 } \\
\text { 塮 } \\
\text { 前 }\end{array}$} & \multicolumn{5}{|r|}{ 注 } & \multicolumn{2}{|l|}{ 射 } & \multicolumn{3}{|l|}{ 後 } & \multirow[b]{2}{*}{$3 n$} & \multirow[b]{2}{*}{$4 "$} \\
\hline & & & & $1 / 12$ 時 & 6 , & $1 / 4$ & $1 / 3$ & $.5 / 12$ & $1 / 2 "$ & $2 / 3$ & $5 / 6 "$ & $1 "$ & $2 "$ & & \\
\hline 1. & 9 & \multirow{3}{*}{ Pitughl. } & - & + & + & $t$ & $t$ & $\frac{1}{1}$ & $H$ & Hit & 州 & tH & 传 & HH & Ht \\
\hline 2 & 13 & & - & + & + & 4 & $H$ & it & H & m & 光 & Ht & tt & Ht & 北 \\
\hline 3 & 12 & & - & + & H & $H$ & $H$ & Ht & 计 & IIt & ty & $H$ & $H$ & H & Hit \\
\hline 4 & 10 & \multirow{3}{*}{$\begin{array}{c}\text { Pitugl. } \\
+ \\
\mathbf{N}(0,1)\end{array}$} & - & + & + & $\pi$ & $H$ & ti & tit & IIt & ttt & $\#$ & 米 & HH & WI \\
\hline 5) & 15 & & - & + & + & + & 4 & 4 & $\pi$ & ttt & Hit & tit & H & Ht & H \\
\hline 6 & 11 & & - & $\frac{1}{1}$ & + & $t$ & 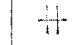 & 4 & $H$ & 116 & Hit & $H i$ & $H$ & tit & $4 i$ \\
\hline 7 & 14 & \multirow{5}{*}{$\begin{array}{c}\text { Pitugl. } \\
+ \\
\text { N. }(0,5)\end{array}$} & - & - & + & + & $t$ & + & $H$ & $i$ & it & $H$ & $t$ & $t$ & -+ \\
\hline 8 & 15 & & - & - & + & + & + & + & $t$ & + & + & + & + & - & - \\
\hline 9 & 11 & & - & - & - & + & + & + & + & + & + & $t$ & + & + & $t$ \\
\hline 10 & 13 & & - & - & - & $t$ & + & + & + & 1 & + & + & + & t. & + \\
\hline 11 & 10 & & - & - & + & + & + & + & $H$ & 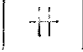 & 4 & $H$ & 4 & 计 & + \\
\hline 12 & 12 & \multirow{5}{*}{$\begin{array}{l}\text { Pitugl. } \\
\frac{1}{\frac{1}{1}} \\
\text { N. }(5,0)\end{array}$} & - & - & - & - & - & - & - & - & - & - & - & + & - \\
\hline 13 & 10 & & 一 & - & - & - & - & - & - & - & - & 一 & - & - & - \\
\hline 14 & 15 & & - & + & - & - & - & 一 & - & - & - & - & 一 & + & - \\
\hline 15 & 14 & & 一 & - & - & - & - & - & - & - & - & - & - & - & - \\
\hline 16 & 12 & & - & + & - & - & - & - & - & - & - & - & + & + & - \\
\hline
\end{tabular}

注澺： N: Novocain, Pitugl: Pituglandol $0,03 \mathrm{ccm}$ 䍌 $10 \mathrm{~g}$ 各適用.

第 8 表二示ス如ク Pituglandol $(0,03 \mathrm{ccm}$ 對 $10 \mathrm{~g})$ フ單獨二作胆セシメタル際八注射前 球形ナリシ Melanophoren ハ何レモ5分後ニシテ稍々摭張シテ短笑起星狀トナリ，10-15 分後ニシテ更二長突起星狀タ示シ，25-40 分後ニシテハ何レモ極度二推張シテ網狀トナレ

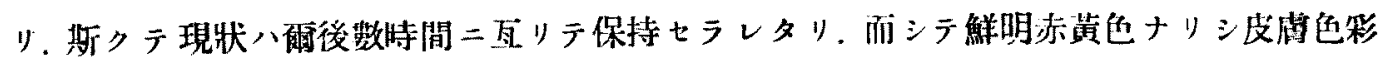
八極度二着色七ラレテ䐺黑赤仙トナレリ。

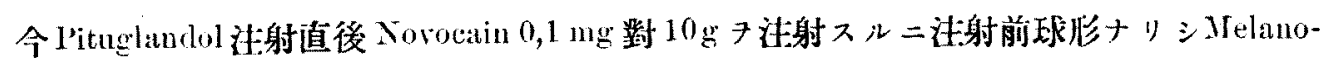

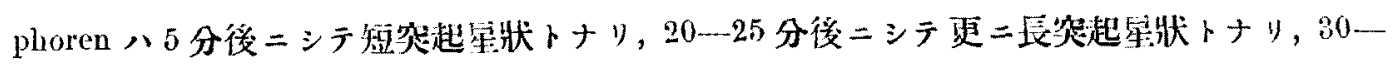

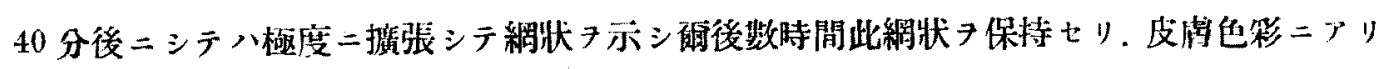

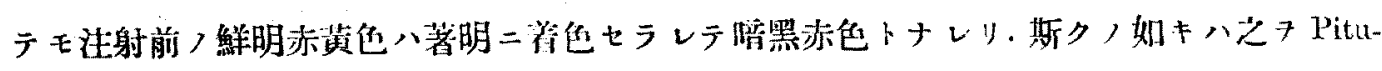

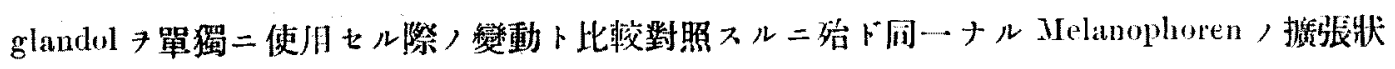

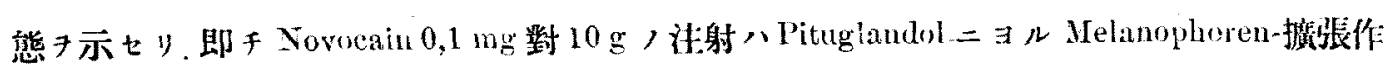

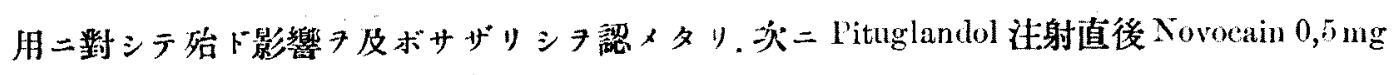

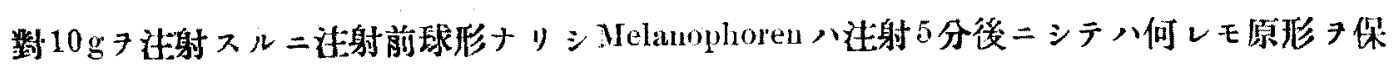

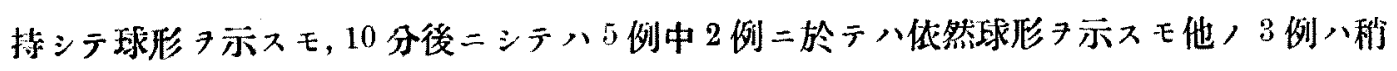

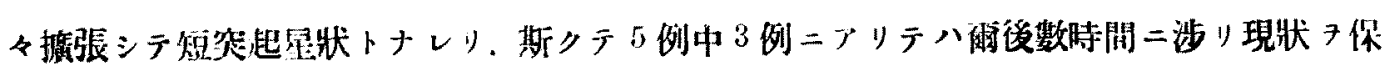


持スルモ他，2例ニアリテハ省摭張シテ長突起星狀トナリ爾後數時間二互リテカ、ル狀態 ヨ保持シテ然ル後原形二向ツテ復歸スルチ示セリ。而シテ注射前鮮明赤黃色ナリシ皮虚色 箖モ稍々着色七ルキ示セリ、斯ク，如キハ之タ Pituglandol 7 單獨二使用セル際，變動二比

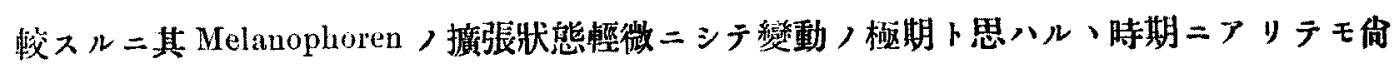

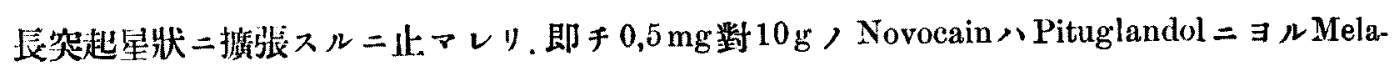
nophoren-擴張作用二黝シテ稍々著シク抑制的二作用スルチ認メタリ。更二5,0 mg 對 $10 \mathrm{~g}$ ，

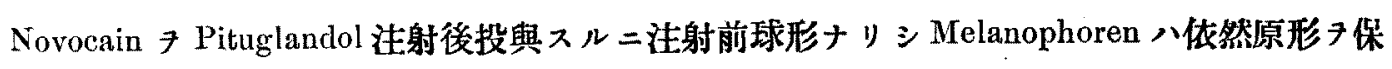

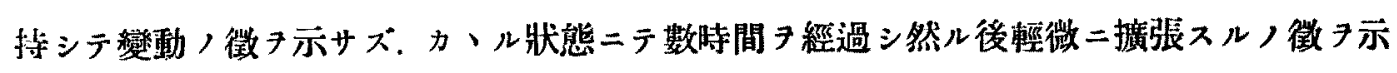

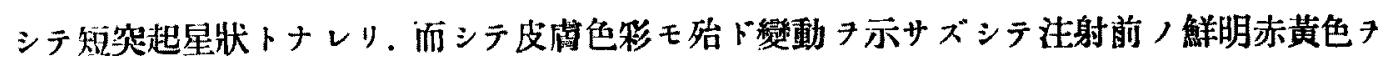
保持セり.斯ク，如キハえフ Pituglandol 7單獨二作用セシメタル際ノ變動二比較スル二殆

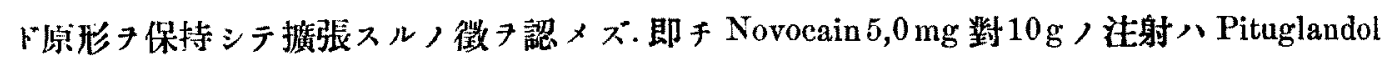
ニョル Melanophoren-擴張作用二對シテ殆ド全ク抑制的二作用スルタ認メタリ.

以上，如》 Pituglandol $=ヨ ル$ Melanophoren-攄张作用二對シテ Novocain 0,1 mg 對 $10 \mathrm{~g}$ 注射ハ㱠ド影響ナキモ，0,5 mg 對 $10 \mathrm{~g}$ 八稍々著明 $=, 5,0 \mathrm{mg}$ 對 $10 \mathrm{~g}$ 八殆ド全ク抑制的二 作用スルタ認メタリ。

\section{總括}

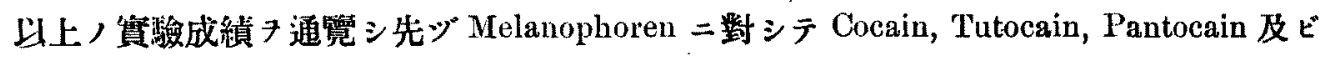
Novocain，及ボス作月ヨ比較スルニ何レテ小量ヨリ大量二至ル迄大䄪其用量二比例シテ

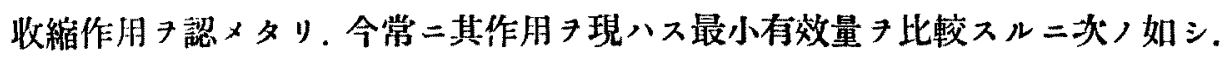

\begin{tabular}{|c|c|}
\hline 藥物 & $\begin{array}{c}\text { 最小有效量 } \\
(\mathrm{mg} \text { 對 } 10 \mathrm{~g})\end{array}$ \\
\hline Cocain & 0,1 \\
\hline Tutocain & 0,1 \\
\hline Pantocain & 0,05 \\
\hline Norocain & 0,5 \\
\hline
\end{tabular}

而シテ上記 4 種，藥物ハ大量注射ニアリテハMelanophoren ノ完全ナル收縮作用キ來スト同時二巠杽發

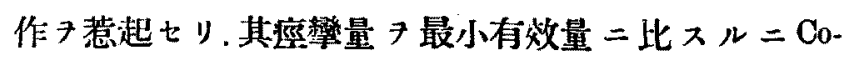
cain 及ビ Tutocain 八何レモ20倍，2,0 mg對 $10 \mathrm{~g}$ 示

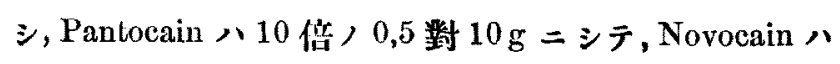
20 佔, $10,0 \mathrm{mg}$ 對 $10 \mathrm{~g}$ タ示セリ。

次 = Pituglandol $(0,03 \mathrm{ccm}$ 對 $10 \mathrm{~g})=\exists ル$ Melanophoren-擴偯作用二對シテモ上記 4 程，樂物、何レモ大略其用量二比例シテ抑制的二作用スルフ認メタリ. 其完全二抑制スル

\begin{tabular}{l|c}
\hline 菜 & $\begin{array}{c}\text { 著明㧕制量 } \\
(\mathrm{mg} \text { 䡒 } 10 \mathrm{~g})\end{array}$ \\
\hline Cocain & 1,0 \\
Tutocain & 1,0 \\
Pantocain & 0,2 \\
Novocain & 5,0
\end{tabular}

注射量き列記スレバ次ノ如シ.

即于抑制的作朋强度ヨリミルトキハPantocain ガ 最モ强ク，次デ Cocain 及ビ Tutocain ニシテ, Novocain ガ最下位キ示セリ。 


\section{松田論文附錄圖}

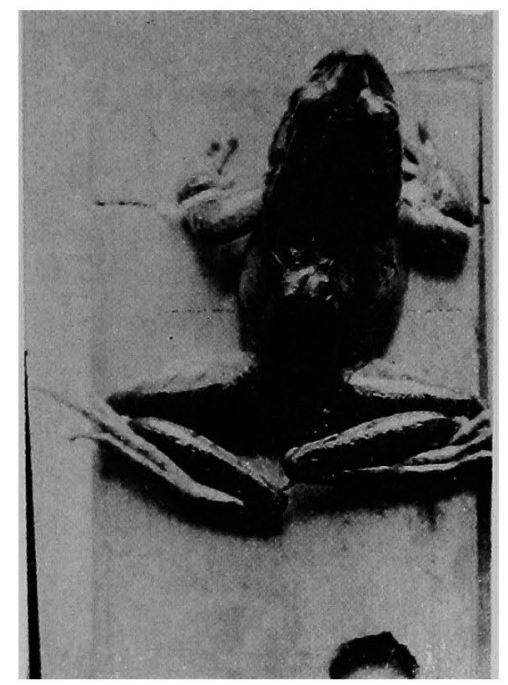

A

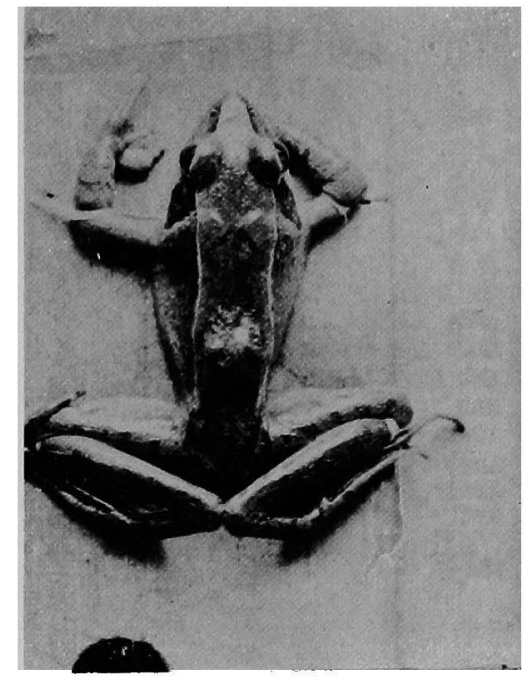

B

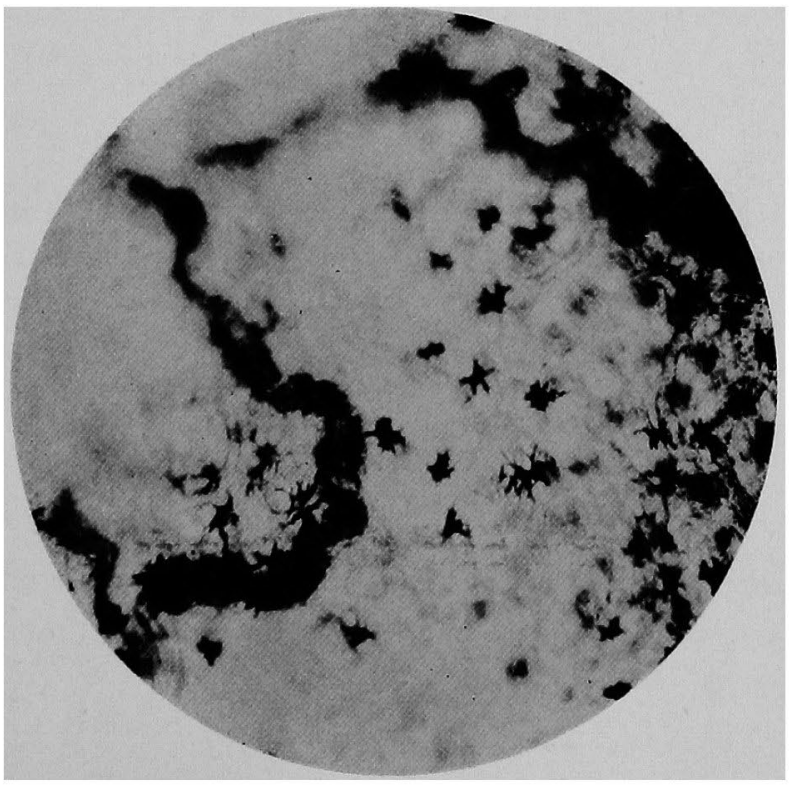

C 


\section{結 諞}

Pituglandol 固有 / Melanophoren-擴张作用二對シテ Cucain, Tutucuin, Pantocain 及ビ Novocain ハ何レモ抑制的二作朋ス，而シテ Cocain, Tutocain, Pantocain 及ビ Novocain 夫レ 自體、Melanophoren 二数 シ收絔的二作用ス。

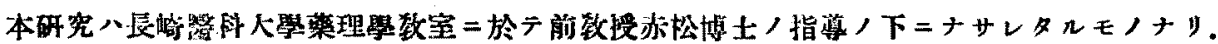

\section{引用書 目}

1) Love: Journ. of exp. Zool. 23, 147 (1917).

2) v. Frisch: Fgü̈gers Arch. 138, 319 (1911).

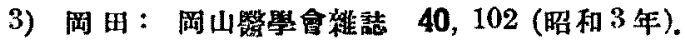

4) 松田：日本菜物學棌誌 19,377 (昭和 10 年)。

5) 松日：同誌 20,91 (昭和 10 年).

\section{坿錨圖說明}

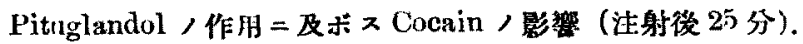
A. Pituglandol $(0,03$ ccrn 對 $10 \mathrm{~g})$ ，際/皮倩色彩.
B. Pituglandol + Cocain $(0,1 \mathrm{mg}$ 對 $10 \mathrm{~g})$ 八際/度有色彩.
C. (B) /際二於ヶ几短突起至狀トナレル Melanophoren. 